\title{
DEVELOPMENT OF THE COMMERCE CLAUSE OF THE CONSTITUTION.
}

A constitution is a living instrument. Framed at the beginning of a nation its purpose is to provide a national rule of action for all time and through every stage of the nation's development. The makers of a constitution may have in their minds particular applications of the language used, but no such limitations attach to the words themselves. The language may, in the course of events, become applicable to conditions beyond the imagination of those who adopted it. The framers of a constitution, of all men, may build better than they know.

The words of a written constitution are changeless, but their meaning is not always the same. In the light of experience words possess new meanings in men's minds. History interprets constitutional provisions. The crisis of a nation make things clear which were in doubt before. The rule that in the interpretation of written instruments the object is to ascertain the intention of the makers is not, therefore, wholly controlling in the construction of constitutional provisions. The purpose of the framers of a constitution may properly be considered as an element in its interpretation, but the practical application of its provisions must always be determined in view of changed economic conditions and of the fundamental principle that a constitution, whenever framed, is always a present rule of national life.

The principle of constitutional evolution through interpretation is most strikingly illustrated in the case of the commerce clause of the Constitution of the United States. The federal commercial power-the essentially nationalizing power-has been brought out through the interpretation of the commerce clause, in the light of history and the nation's growth, by the Supreme Court of the United States. The series of decisions marking that development mark, also, American commercial progress and furnish the most enduring monuments of the greatness of the tribunal which rendered them.

An examination of the history of the times prior to the adoption of the Constitution shows that the regulation of foreign commerce was demanded by the exigencies of the Union. The Articles of Confederation reserved to the states the right to levy duties, except 
such as might interfere with stipulations in the treaties with France and Spain. The commerce of the country was under the control of the state legislatures. It was the commerce of thirteen states and not of a single nation. Diverse regulations caused confusion and clashing. The preservation of American shipping required the adoption of a navigation act. The existence of the United States as a commercial power made necessary a central authority to control intercourse with all the states. The financial difficulties of the Confederation showed plainly the necessity for a national means of raising national revenue. The Confederation was a government with power to incur obligations, but without power to discharge them. National debts were parcelled out among the states and thirteen independent legislatures granted or withheld the means of payment. The credit of the nation demanded that a national revenue should be provided, and a tariff on imported goods furnished a readily available method of raising it.

At the time of the adoption of the Constitution commerce among the states existed only in a small way. The states lay along the seaboard and the principal means of communication was by sailing vessels. Stage coaches, wagons and pack-horses furnished the means of inland transportation. There were few manufactories, and those which existed usually supplied only the markets in their immediate vicinity. The necessaries were produced at home. The luxuries were brought from abroad. The slight interstate trade that existed, moreover, was impeded by the imposition of duties by the different states upon the traffic across their borders. The levying of imposts by the states upon goods brought in from other states was an easy means of raising revenue-a means appealing alike to selfishness and local prejudice. That such imposition could only result in rivalry between the states and the elimination of all common interests was generally acknowledged and the necessity for their abolition was generally felt. But there is no indication in the history of the times nor in the debates in the Constitutional Convention that any other or further regulation of interstate commerce was contemplated.

The Convention met and framed a Constitution containing this provision: "The Congress shall have power . . . to regulate commerce with foreign nations, and among the several states and with the Indian tribes." By the adoption of this clause in its grant of legislative powers the Constitutional Convention created the federal commercial power and provided for unity of commercial regulation. 
The adoption of the commerce clause marked an epoch-the beginning of the development of commercial supremacy from commercial chaos. And yet no member of the Convention appreciated the possibilities of the language used. There is nothing to indicate that anything further was intended than the uniform regulation of foreign commerce and the prevention of imposts at state lines. Certainly the people had in mind foreign commerce when they bore the ship "Federal Constitution" with colors flying, as the central figure of the pageants in honor of the ratification of the Constitution.

But while the purpose of the framers of the Constitution in respect of interstate commerce was limited in its scope the language used was broad and comprehensive and has become applicable to conditions incomparably changed. The growth of the nation in territory and population has only kept pace with mechanical and scientific development in furnishing means of transportation. Foreign commerce is now insignificant when compared with interstate commerce. The amount of merchandise transported across state lines is stupendous. The power conferred upon Congress to regulate this commerce among the states-to control transportation and intercourse-is among the great powers of the federal government. As a nationalizing power-a power which works towards one nation instead of a collection of states-it is the most important power of all. Power in the general government to regulate foreign commerce is essential to the standing of the United States as one of the commercial powers of the world. Power to regulate interstate commerce is essential to the upbuilding of a great nation.

And the development of the federal commercial power has resulted from the definitions of two words. The Constitution grants to Congress power to "regulate commerce." As already shown, a narrow meaning given to those words would have been in accordance with the intention of the framers of the Constitution, as that intention may be gathered from the history of the times. Neither the word "commerce" nor the word "regulate" is a word of precise meaning, and it was necessarily left to the Supreme Court, by defining the words, to broaden or limit the power. The widening scope of the commerce clause has followed from the broadening definitions of the words, "commerce" and "regulate."

The word "commerce" might have been defined, in the language of the dictionary, as "an exchange of merchandise between different places," and as an equivalent for "trade;" and the purpose of the Constitutional Convention, in providing for national duties on imports and preventing imposts at state lines, would have been fully 
met. Moreover, the regulation of trade with foreign countries has never required that the word "commerce" should receive a broad definition. On the other hand, the existence of an effective federal power in respect of interstate commerce does require that that term should be held to include, broadly, all commercial intercourse between the states.

The Supreme Court has met the exigencies of the case. It has said that the word "commerce," as used in the commerce clause, "is a term of the largest import" and has given this definition: "Commerce among the states consists of intercourse and traffic between their citizens, and includes the transportation of persons and property, and the navigation of public waters for that purpose, as well as the purchase, sale, and exchange of commodities." (Gloucester Ferry Company v. Pennsylvania, I I4 U. S. 203.)

An analysis of this definition shows that interstate commerce. includes:

(I) The transportation of property from one state to another.

(2) The transportation of persons from one state to another.

(3) The navigation of public waters for transportation purposes.

(4) The purchase, sale and exchange of commodities between citizens of different states.

This broad definition of interstate commerce has been the result of gradual growth. In the earliest interstate commerce case, the great case of Gibbons v. Ogden, 9 Wheat. I, it was held that the word commerce comprehended navigation, and that a power to regulate navigation was as expressly conferred as if that term had been added. Extending this doctrine, it is held that navigation involves the control of navigable waters, and necessarily includes the power to keep them open and free from obstruction, and to make improvements in them. This conclusion that the federal government, under the commerce clause, has power to authorize improvements in waters within the limits of a state, is a striking illustration of the principle that history, and the nation's necessities may outweigh the intention of the framers of the Constitution.

The word "commerce," upon its face apparently refers to the traffic in commodities; but it is held also to include the transportation of passengers from state to state, their embarkation and disembarkation. Transportation is, however, an essential element of commerce. Without transportation there can be no commerce. Production, therefore, is not commerce. "Manufacture succeeds to commerce and is not a part of it." While the operation of a manu- 
facturing establishment necessarily involves the shipment of its product, the process of manufacture is distinct from the process of transportation. The former process is the subject of state regulation; the latter, of federal control. Similarly, banking and insurance do not constitute commerce, because they do not involve the element of transportation.

The broadening power over interstate commerce given to Congress by the decisions is, however, even more clearly shown in the widening definition of the word "regulate" than in the case of the word "commerce." If, as said by President Monroe in a message to Congress, nothing more was intended than to prevent the imposition of duties by states upon goods brought in from other states, the word "regulate" was very limited in its scope. And the circumstances surrounding the adoption of the commerce clause also support the view that the power was intended to be limited and, to a certain extent, concurrent with the powers of the several states. The motion to give Congress the "sole and exclusive" power over commerce was lost in the Constitutional Convention. That the power of Congress was merely concurrent with that of the states and involved no prohibition of state action not inconsistent with federal laws was, moreover, the opinion of the attorney-general immediately after the adoption of the Constitution (Opinion of Edmund Randolph, attorney-general, Feb. I2, I79I), and of different state courts.

It was acknowledged from the beginning that the power of Congress, when exercised, was paramount. The essential question was whether it was exclusive or concurrent. This question was first answered in Gibbons v. Ogden, supra, in which Chief Justice Marshall said that the federal commercial power was indivisible and therefore exclusive of a like power in a co-ordinate sovereignty. The underlying principle is, that the power to regulate being the power to restrain, the grant of power to regulate necessarily implies power to determine what shall remain unrestrained. Inaction by Congress is equivalent to an affirmative declaration that no action is desired. Accordingly, while the decision in Gibbons $v$. Ogden has not always been followed, it is now well settled by the Supreme Court of the United States that, with respect to all subjects national in character and admitting uniformity of regulation, the federal con:mercial power is not only paramount, but exclusive.

Interstate commerce, consisting of the sale, exchange and transportation of commodities and the transportation of persons manifestly admits of uniform regulation, and is subject solely to the control of Congress. The states are without power to impose any burdens upon such commerce, or to interfere with it in any way. It is 
only in the case of local matters-in matters which are rather auxiliary to commerce than a part of it-that the states have power to act in the absence of action by Congress.

The Supreme Court has many times said that the power to regulate commerce is to prescribe the rule by which it is to be governed. But this observation must always be read in the light of the likewise often repeated statement of the court that the power of Congress under the commerce clause is plenary, complete in itself and subject to no limitations other than those to be found in the Constitution. A wide discretion is left to Congress in exercising the power conferred. It may go further than to determine the manner in which the various kinds of commerce shall be carried on. As held by the Supreme Court in the Lottry Case, I88 U. S. 321, legislation under the commerce clause may sometimes assume the form and have the effect of prohibition. How far this doctrine will be carried-whether, for example, a statute prohibiting monopolistic corporations from engaging in interstate commerce would be held to be a legitimate exercise of the power of Congress-remains to be seen.

While Congress was granted by the Constitution plenary power over interstate commerce it practically failed to exercise it for a hundred years. The development of the federal power which we have noted was rather in a negative than in a positive way. The Supreme Court was called upon to say what the states could not do instead of what Congress could do-except as the one necessarily followed from the other. It was in determining the constitutionality of state legislation that the great principles which we have outlined were laid down. In 1887 , however, Congress passed the Interstate Commerce Act, and, in 1890, the Sherman Anti-Trust Act. Both of these measures are of great and increasing importance. In the one, as amended, a comprehensive system for the control of carriers engaged in interstate commerce is stated, and in the other all combinations in restraint of such commerce are prohibited.

We have thus traced the outline of the development of the federal commercial power. And the end is not yet. The tendency in this country toward a centralization of power is increasing. The field of the national government is constantly widening. The nation is dealing more and more with problems formerly thought to belong exclusively to the states. A unity is growing out of a union. And the primary source of all this nationalizing power is the commerce clause of the Constitution. Walter C. Noyes, Judge of the Court of Common Pleas, New London County, Conn. 